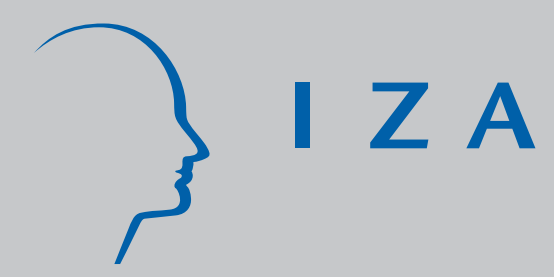

IZA DP No. 2461

Intermarriage, Language, and Economic Assimilation Process: A Case Study of France

Xin Meng

Dominique Meurs

November 2006 


\title{
Intermarriage, Language, and Economic Assimilation Process: A Case Study of France
}

\author{
Xin Meng \\ Australian National University \\ and IZA Bonn \\ Dominique Meurs \\ ERMES, University of Paris II
}

Discussion Paper No. 2461

November 2006

IZA
P.O. Box 7240
53072 Bonn
Germany

Phone: $+49-228-3894-0$

Fax: +49-228-3894-180

E-mail: iza@iza.org

Any opinions expressed here are those of the author(s) and not those of the institute. Research disseminated by IZA may include views on policy, but the institute itself takes no institutional policy positions.

The Institute for the Study of Labor (IZA) in Bonn is a local and virtual international research center and a place of communication between science, politics and business. IZA is an independent nonprofit company supported by Deutsche Post World Net. The center is associated with the University of Bonn and offers a stimulating research environment through its research networks, research support, and visitors and doctoral programs. IZA engages in (i) original and internationally competitive research in all fields of labor economics, (ii) development of policy concepts, and (iii) dissemination of research results and concepts to the interested public.

IZA Discussion Papers often represent preliminary work and are circulated to encourage discussion. Citation of such a paper should account for its provisional character. A revised version may be available directly from the author. 
IZA Discussion Paper No. 2461

November 2006

\begin{abstract}
Intermarriage, Language, and Economic Assimilation Process: A Case Study of France

Lack of economic assimilation of immigrants often results in social and political unrest of a society. The increased desire to understand better the nature of the assimilation process of immigrants is due to increased immigration flows in many western countries. In this paper we try to study the role of intermarriage in the process of immigrant economic assimilation in France. We find that among all immigrants those who are intermarried earn around 17 per cent more than those who are endogamously married. Once taking into account individual characteristics and endogeneity of intermarriage, the premium is around 25 to 35 per cent. In addition, the intermarriage premium is substantially higher for individuals who have better grasp of French language before migration than for those whose language skill is poor. This result seems to suggest that, perhaps, immigrants who have a strong base in the native language can better reap the gain from intermarriage.
\end{abstract}

JEL Classification: J61, J12

Keywords: immigration, economic assimilation, intermarriage

Corresponding author:

Xin Meng

Division of Economics

Research School of Pacific and Asian Studies

Australian National University

Canberra 0200

Australia

E-mail: Xin.Meng@anu.edu.au 


\section{Introduction}

Many western countries have recently experienced social unrest due to lack of immigrant assimilation and, in response, there has been an increased desire to understand better the nature of the assimilation process. The recent disruptions in France, stemming from high unemployment rates and low incomes among the first and second generation immigrants, and the resultant questioning of immigrant assimilation policy, is a recent example Understanding the assimilation process is of significant policy relevance for a wide range of countries.

Previous economic integration studies have focused on the speed of economic assimilation, mainly in the US, the UK, Canada, and Australia (Borjas, 1985, 1995; Chswick, 1978; Bell, 1997; and Baker and Benjamin, 1994). More recently studies by Chiswick and Miller (1995), Lazear (1999), Dustmann and Van Soest (2002), and Dustmann and Fabbi (2003) have analysed the role of native language acquisition and found that those with better language skills assimilate much faster. Meng and Gregory (2005) examined immigrant marriage patterns and found that immigrants who intermarry assimilate better and, on average, earn around 20 per cent more than those who do not. Meng and Gregory (2005) attribute a significant part of this labour market reward to the effect of the marriage on the acquisition of native language skills and a better understanding of local labour markets. Unlike the Australian study Kantarevic (2005) finds no causal effect of intermarriage on earnings in the US.

There are many possible reasons for the differences in the Australian and US findings. In particular, Australia has a strong preference for skilled immigrants while in the US a large proportion of immigrants are unskilled workers (reference). In addition, a large proportion of US immigrants are from Latin-American countries while the majority of Australian immigrants are from Asian or European countries. Further, "natives" in Australia is a relatively uniform population group, whereas in the US "natives" can be white or black, which have very different labour market outcomes, and hence, significant difference in labour market networks.

In this paper, we take up the intermarriage theme in a third country and investigate its relevance for immigration assimilation in France. Unlike either Australia or the US, France operates under a very restrictive immigration policy since the 1970s, whereby most recent 
immigrants enter under family reunion or refugee schemes (Constant, 2003). In addition, a large proportion of the immigrants is from either other European countries (45 per cent) or from Africa (40 per cent).

In addition, France may provide an opportunity to be empirically more precise about the effect of intermarriage on language improvement relative to the acquisition of more local labour market knowledge and better networks. Due to data limitations, Meng and Gregory (2005) could not empirically distinguish between these two channels of improved labour market earnings. The advantage of French data is that many immigrants are from African countries, where French is either used as an official language or as the language of schools, but the labour market institutions are very different. For these immigrants, therefore, intermarriage should not deliver language gains and the effect of intermarriage on earnings should mainly arise from other sources including a better understanding of local labour markets.

We find that among all immigrants those who are intermarried earn around 27 to 37 per cent more than those who are endogamously married. In addition, the intermarriage premium is substantially higher for Africans (who have much better grasp of French) than for non-Africans, which seems to suggest, perhaps, that immigrants who have a strong base in the native language can better reap the gain from intermarriage.

The paper is structured as follows. The next section introduces background details. Sections 3 and 4 describe data and estimation strategy, respectively. Sections 5 presents the results. Conclusions are given in section 6 .

\section{Background}

After the WWII, in response to labour shortages, there was a large demand from French employers to hire workers from former colonial countries such as Tunisia, Morocco, and Algeria. However, in response to the Algerian war (1954-1961), the French government began to diversify the country source of work related immigrants and agreements were signed with Spain (1961), Portugal (1963), Yugoslavia and Turkey (1965).

French immigration policy also responded to the 1973 oil crisis and since 1974 immigration 
has been strictly controlled and work related immigration limited to specific demands from employers. Because of the tight regulations, it became difficult to stay and work in France legally. As a consequence, illegal immigration has been increasing which has led to periodical legalisation of illegal immigrants (in 1981 and 1998). There has been major refugees inflows: Vietnamese in 1975 and more recently from refugees from Africa and Yugoslavia. Interestingly, although the Open Border policy among EU countries has been introduced for many years, immigrants from old EU member countries are limited, while immigration from recent EU members is increasing.

The above patten of the different waves of immigration is presented in Figure 1. Using data from the 1992 special immigration survey, Figure 1 indicates that work related immigration dominated the pre-1974 immigration share, whereas family reunion and refugees dominated the post 1974 period. We also present the composition of immigrants from different country of origin in Table 1 using data from 1999 census. It shows that immigrants accounted for 7.4 per cent of the total population in France. Among them, 45 per cent is from European countries, mainly Portugal, Spain, and Italy, and 39 per cent is from Africa.

One special feature of immigrants in France is worthnoting, which is that most African immigrants had very good grasp of French before they came to France, especially for the more educated people. French was the official language for all of French colonial countries. It still is the official language in former colonies from black Africa (Sénégal, Mali, Côte d'Ivoire) after their independence. For Arabian countries (Morocco, Tunisia, Algeria), however, French is no longer the official language since their independence but still is the language used for everyday purposes. Since the 1980s, there is a movement towards the arabisation of the education system and the society, but the movement has progressed at a rather slow pace. In Morocco and Tunisia, French is still used from the primary school. A large part of secondary education is taught in French, while almost all the tertiary education is taught in French. Algeria is the only country which shifted towards a complete arabisation at primary and secondary level in the late 1980s. To study French as a second language is, nevertheless, compulsory. In addition there are private schools which provide complete French education. At tertiary level education in Algeria is still given mainly in French. 
Very few studies have devoted to the issue of economic assimilation of immigrants in France. Using 1990 census, Moaurin (1991) calculated a risk of unemployment for North African immigrants that was $79 \%$ higher than the French natives, while for Portuguese immigrants it was 49\% lower. Dayan et al. (1997) studied the professional mobility using the 1992 special immigrant survey. Their main conclusion is that immigrants are trapped in low-skilled occupations and did not experience an upper professional mobility as their French counterparts over their working life. Most recent papers are limited to the study of second generation immigrants and examines the discrimination they experience in finding a work (Dupray et al., 2003 and Fournier et al., 1999). Using 1999 survey, Meurs et al. (2005) presented an outline of the situation on the labour market for different generations of migrants, according to the country of origin (or the country of origin of their parents). They find that the risk of being unemployed for African immigrants is still as high as in Maurin's (1991) study ten years later. Moreover this disadvantage is only slightly reduced for second generation African immigrants.

The family structure of immigrants has been studied by demographers and sociologists (see,

for example, Tribalat \& al., based on MGIS 1992). An overview of marriage, intermarriage and fecundity is presented in Borrel et al. (2003). Using the data from the census 1999, they find that 38 and 34 per cent of male and female married immigrants are intermarried, with large variations across the country of origin. European immigrants (mainly Spanish and Italians) are more inclined to have mixed marriages, with a rate close to 50 per cent, as opposed to Turkish immigrants for whom the rate of intermarriage is the lowest among all immigrants (14 per cent for the married males and 4 per cent for the married females). Portugal and North African immigrants are between these two extreme cases with a rate of intermarriage between 20 and 30 per cent, respectively.

\section{Data}

Studies on economic assimilation and intermarriage mainly use census data. Unfortunately, French censuses do not include income or earnings variables. Data used in this study is from a special immigration survey conducted by INSEE (National Institute of Statistics and Economic 
Studies) and INED (National Institute of Demographic Studies) in 1992. The survey comprises three groups, a group of immigrants; a group of second generation immigrants who are aged 20 to 29 years and whose father immigrated from Algeria, Spain and Portugal; and a group of individuals who are representative of the general population. The sample frame was the 1990 census. For the purpose of this study only the immigrant sample is used. 11979 individual immigrants were interviewed and 8522 questionnaires were collected. These immigrants are a random sampling of people from the following 7 regions (countries and groups of countries) were included: Spain, Portugal, Algeria, Morocco, Turkey, Asia (Cambodge, Laos, Vietnam,) Sub-Saharan Africa. As indicated in Table 1, these 7 regions accounted for 63 per cent of the total immigrant population in 1999 census. The survey interviews individuals aged 20 to 59 years and if more than one person in a household are suited for the survey, one was selected randomly using Kish method.

The survey comprises detailed information on personal characteristics (such as age, gender, education, religion, and other subjective information such as beliefs), history of immigration (such as year of arrival, motive for migration, presence of relatives or friends in the country of destination), work characteristics (labour force status, seniority for salaried workers, ethnic composition of co-workers, earnings, and hours worked ${ }^{1}$ ), marital history (marital status, duration of marriage or partnership, number and age of children), as well as information on spouses such as country of birth, year of arrival for migrants if spouse is a immigrants, and labour force status. In addition, the survey also provides detailed information on French proficiency. ${ }^{2}$ Two independent assessments of individuals' French proficiency at the time of the survey were collected: a self-assessed indicator and an assessment by the interviewer. The interviewer as well as the individual immigrants themselves were required to rank individuals' French ability from 1 (good), 2 (fair) to 3 (do not speak French at all). Moreover a question on immigrants' social life was explicitly used as a reading test. The interviewees were provided with a code of

\footnotetext{
${ }^{1}$ Information on annual earnings was collected for the year 1991 in 11 broad brackets. Following Chiswick and Miller (1985) we derive our annual earnings using the midpoints of the income intervals and using a value of 1,5 the lower (upper) threshold for the open-ended lower (upper) categories. Information on the number of months worked in 1991 and the number of usual hours worked in a week is also available. Combining earnings and hours worked information we derive information on hourly earnings.

${ }^{2}$ As interpreters were available at the time of the survey, the coverage of the survey was not limited to people who can speak French.
} 
12 possible answers for this question and were required to read the code and then fill in the answer. Only when an immigrant was not able to read it, the interviewer was allowed to help him/her in reading aloud the code. As previously, the individuals were thus ranked with a three levels scale: 1 (read well), 2 (read with difficulty), and 3 (cannot read at all). Immigrants were also asked a retrospective question of "Did you speak French before coming to France?", and was required to give an answer of yes or no.

As we are interested in the effect of intermarriage on labour market outcome, the sample used is limited to married or de facto immigrants who arrived as unmarried individuals. This selection rule allows us to focus only on people who clearly chose to be intermarried, but at the price of the loss of a substantial number of observations, especially for women immigrants as a large proportion of immigrant women came to France under family reunion scheme (see Figure 1). Of the original 8522 observation, 6655 (75 per cent) declare to be married or in a de facto relationship at the time of the survey and 3685 (2422 males and 1263 females) were not married when they arrived to France. 82 per cent of these married males are working and 72 per cent are wage earners. The percentage of working females is lower (56 per cent working and 50 per cent are wage and salary earners). Excluding missing values, our final sample comprises 1664 and 557 male and female wage and salary earners, respectively ${ }^{3}$.

Intermarriage is defined as an immigrant who lives with somebody who is French by birth. ${ }^{4}$ Table 2 presents the intermarriage rates for male and female samples. For the total sample (8522) 13 per cent and 18 per cent of male and female immigrants are intermarried, respectively. Whereas for our final sample of 3685 individuals the ratio is $35 \%$ and $33 \%$ for male and female immigrants, respectively. These ratios are consistent with those revealed from the 1999 census, which shows that 38 per cent male and 35 per cent female immigrants were intermarried. European immigrants have the highest probability of intermarry (46 and 50 per cent for males and females, respectively), while only less than 6per cent of Turkish women and 9 per cent of Turkish men are intermarried. The proportion of intermarriage for immigrants from African countries is around 20 per cent. These differences between countries are consistent

\footnotetext{
${ }^{3}$ To test the sensitivity of our sample exclusion restrictions, we also present results from total sample of wage and salary earners later in the paper.

${ }^{4}$ By definition an immigrant who married to a second generation immigrant is considered as intermarried.
} 
with the general results from the 1999 Census (Borrel, Tavan, 2003). To disentangle the effect of intermarriage through language improvement on earnings and through local labour market knowledge and network on earnings, we also separate our samples into those who are from African countries and those who are not.

Table 2 also provides summary statistics of the main characteristics of the sample by the type of marriage. Broadly speaking intermarried immigrants appear to be younger than their endogamous counterparts. They arrived at earlier age and are more educated. 79 per cent and 76 per cent of female and male intermarried immigrants spoke French before their migration, respectively, whereas the ratios for their endogamously married counterparts are 60 and 52 per cent for females and males, respectively. Over 94 per cent of men participate in the labour market, intermarried or not, while the rate for female is slightly different with intermarried women participating in the labour market at 73 per cent and endogamously married women 71

per cent. Regarding to the most important issue for this paper, we observe a positive pronounced raw wage premium for intermarried immigrants, equal to $17 \%$ for both males and females.

We also present the summary statistics for immigrants from Africa and non-africa countries. We find that Africans are more likely to speak French before migration and African immigrants who are wage adn salary earners are on average more educated than non-Africans. In addition, they are less likely to be intermarried.

\section{Analytical strategy}

Our main interest is to examine whether intermarriage facilitates economic assimilation of immigrants in France. Following the literature, economic assimilation is measured in terms of labour market earnings. Consider the following equations:

$$
\begin{aligned}
\ln \left(Y_{i}\right) & =\alpha_{0}+\alpha_{1} M_{i}+\alpha_{2} X_{i}+\varepsilon_{i} \\
M_{i} & =\beta_{0}+\beta_{2} X_{i}+\beta_{3} Z_{i}+v_{i}
\end{aligned}
$$


where $Y$ is hourly earnings, $M$ is an indicator for intermarriage, and $X$ is a vector of exogenous variables. Because intermarriage and high earnings capacities may both be determined by some unobservable characteristics, $M$ is correlated with $\varepsilon$ in equation (1). Such an endogeneity problem will result in a biased estimation of $\alpha_{1}$ if using OLS. To avoid the problem, we adopt a two stage estimation strategy, which treats intermarriage as endogenous. Equation (2) endogenises intermarriage and $Z$ is a vector of instruments which identifies intermarriage equation.

The vector of exogenous variables, $X$, includes age and age squared, a group of education dummy variables, a dummy variable indicating whether an individual is viewed by the interviewers as speaking French fluently, and year since migration. In addition, we include a group of country of origin variables (Europe (Spain and Portugal), Africa (Algeria, Morocco, others Sub-Saharan African countries), Asia, and Turkey) as proxies for the transferability of labour market skills and a dummy variable indicating the place of residence (Paris opposed to the rest of the France) to take into account regional wage variations. Further we also control for whether an individual has a religion which may indicate whether he/she is open minded, which in turn may affect productivity and intermarriage (Meng and Gregory, 2005).

The instruments, $Z$, should satisfy the exclusion restriction. That is they should affect the intermarriage decision but have no directly effect earnings except through the impact on intermarriage. We selected the following instrumental variables. The first instrumental variable we us is "Sex Ratio", which is defined as $S R A T I O_{m}=N_{j f} / N_{j m}$ for males and RATIO $_{f}=$ $N_{j m} / N_{j f}$, where the subscripts $m$ and $f$ indicate male or female observations and $j$ indicats a ethnic-age-region cell. $N_{j f}$ and $N_{j m}$ is the number of female and male immigrants of the same country of origin in the same age group and living in the same region. SRATIO measures the competition in a certain ethnic-age-regional marriage market for males (or females). The larger the ratio, the less sever the competition within the group, and the less likely the individual will search for partners outside his/her own ethnic group (Angrist, 2002; Meng and Gregory, 2005).

The second instrumental variable we use is "probability of marry within one's own ethnic group", which is defined as $P R O B_{m}=N_{j f} / N_{f}$ for males and $P R O B_{f}=N_{j m} / N_{m}$ for females. While $N_{f}$ and $N_{m}$ are defined as the same as in SRATIO, $N_{f}$ and $N_{m}$ denote the total number of both French and immigrant women/men of the same age group and the same region. The 
larger the value of this variable, the more likely for an immigrant to meet a partner of the same ethnic-age-region group, and the lower the probability of marry outside one's own ethnic group.

We used the 1999 Census to construct these variables. A cross-tabulation composed of 8 age groups, 20 regions, and 7 countries or groups of countries as defined in our survey is produced by INSEE. Using this table we constructed the variables. These instrumental variables are obviously exogenous to individuals' earnings, at the same time, as we will show later, have statistically significant effect on intermarriage.

Equations (1) and (2) are estimated using two-stage estimation, whereby the first stage predicts for each individual the probability of intermarriage, which in turn is plugged into equation (1) for the second stage estimation.

The above estimation strategy is suitable for the male sample. For females, however, an additional difficulty arises when estimating the earnings equation. As large proportion of females are not working, failure to take into account this selection problem could result in biased estimations of returns on individual characteristics, and, consequently, on the measurement of the intermarried effect. Thus, for female sample, in addition to equations (1) and (2) we also estimate a labour force participation equation and from which a sample selection correction term, the inverse Mills ratio - IMR, is generated and then introduced into the earnings equation together with the predicted probability of intermarriage. To identify the labour force participation equation, we use the number of children aged of less than 6 years and the presence of children aged between 6 and 18 years as instruments. In the next Section we report both regressions with and without the selection correction term.

In addition to estimating the effect of intermarriage on economic assimilation, this paper also intends to isolate the effect of intermarriage through facilitating acquisition of local labour market network and other knowledge on economic assimilation. To do so, we separate our samples into African and non-African immigrants. As discussed earlier, French had been official language in all of African countries in our sample. It is still so in Black African countries. Arabian countries although switched to use Arabic as the official language, French is still used from the primary school as the main language or as a compulsory second language. Thus, everybody who are literate speaks French fluently. For this group, therefore, the effect of 
intermarriage through language improvement on economic assimilation should be very small. Further to this African and non-African divide, we also use "Speaking French before migration" or not to test the robustness of our finding from African/non-African estimations.

\section{$5 \quad$ Intermarriage and Intermarriage premia}

\subsection{Determinants of intermarriage}

We first present results on the determinants of intermarriage. Equation 2 is estimated for all immigrants married after migration and for sub-samples of Africans and non-Africans separately using both the Linear Probability model (LPM) and probit model. The results are presented in Table 3, with the left panel presenting the results for the total sample and the right panel presenting the results for the sub-samples of Africans and non-Africans.

We first discuss the results for the total sample. The results are largely consistent between the LPM and probit model and the discussion below will focus on the probit model. Most variables have expected signs and are statistically significant. Men are more likely to intermarry than women and the difference is almost 7 percentage points. Consider that the average intermarriage rate is around 30 per cent for the sample, the gender difference is considerable. Highly educated are more likely to intermarry as it is observed in Meng and Gregory (2005) and many sociological studies (Qian, 1999 and Qian and Lichter, 2001). The longer one stays in the country since migration the more likely he/she is intermarried. Speaking French before migration and currently speak French fluently both have positive sign and are statistically significant. The dummy variable for no religious belief has a statistically significant positive effect on intermarriage. This relationship was also observed in Australia by Meng and Gregory (2005). Compared to the reference group (Turkey), the probability of intermarry is higher for all other migrants and the highest estimates is observed for European immigrants. Surprisingly, living in Paris reduces one's probability of intermarriage.

Turning to the separate sample for Africans and non-Africans we find that the pattern of intermarriage determinants differs considerably between the two groups. First, gender difference in intermarriage rate is much higher for Africans (13 percentage points) than for non-Africans 
(4 percentage points). Second, education is a more important determinant of intermarriage for Africans than for non-Africans. Third, year since migration does not play an statistically significant role in determine intermarriage for Africans as it does for non-Africans. Finally, the role of language skills, either the knowledge before migration, or the current skills, is more important for non-Africans than that for Africans. Perhaps as majority of Africans speak French fluently, the variation among Africans is not as large as that among non-Africans.

The most important variables for our study are the two instruments. Both variables have the right sign and are statistically significant at the 1 per cent level for the total sample. The probability of intermarriage increases when the sex ratio for the opposite gender decreases. Similarly, an increase in the probability to meet a partner from the same ethnic-age-regional group reduces the likelihood of intermarriage. For the sub samples of Africans and non-Africans, the effects are statistically significant at between the 5 and 1 per cent levels, except for nonAfrican males, where the sex ratio variable is not statistically significant.

\subsection{Female labour force participation decision}

As our outcome variable, hourly earnings, can only be observed when an individual is working as a wage and salary earner, there is a serious sample selection problem, especially for females, which may bias our estimated result for intermarriage. Our total sample of females who were not married before migration and are currently married is 1263 and among them only 50 per cent (630 individuals) are wage and salary earners. The rest of this group women are either not in the labour force (27 per cent), unemployed (17 per cent), or worked as self-employed (6 per cent). Whereas for male 75 per cent of the group is currently worked as wage and salary earners. We, therefore, try to correct for this sample selection bias using Heckman's (xx) sample selection model for the female sample. The participation equation is identified by using two instruments: total number of children and total number of children who are aged 0 to 6 at the time of survey.

Table 4 presents LPM as well as probit model results on the participation behaviour for married female immigrants who arrived in France single. The first two columns are results for the total sample, while column 3 is for Africans while column 4 is for non-Africans. The 
results are largely consistent across the three samples. Age has a statistically significant inverse U-shaped effect on individuals' participation decision. The more the number of young children and the more children in general increase the probability of quitting labour market, which is a sensible and very common finding. Both children variables are statistically significant at the 1 per cent level. In addition, living in Paris increases labour force participation of women. Apart from these variables, nothing else is statistically significant determinant. The insignificant effect of education on labour force participation decision is an unusual finding for native French. This may be due to the fact that immigrants face strong financial constraints, especially those who are less education. Thus, finding a job is more urgent for them than for the more educated. The positive and significant effect of locating in Paris may be related to more opportunities on labour market in this area.

Finally, there is no relationship between intermarriage and labour force participation. Although the intermarriage coefficient has a positive sign on labour force participation for Africans and negative sign for non-Africans, none of the estimates are statistically significant.

\subsection{Intermarriage and wage premium}

We are now turning to our main objective: estimating the earnings premium of intermarriage. Table 5 presents the estimated results for equation (1) from the OLS, IV, and two-stage estimations for the total sample, and for male and female samples, separately.

The pattern of wage determination is consistent across different estimation strategies, but differs somewhat for male and female samples. The difference for male and female samples is also consistent across the three estimations. Hence, the discussion below will focus on the two-stage estimation except when we discuss the intermarriage effect.

For the total sample, age, year since migration, and having above secondary education all have positive and statistically significant impact on earnings, so as speaking French fluently at the time of survey. The results on age and year since migration, however, are mainly driven by male sample. For females, neither duration since migration nor age has a statistically significant impact on earnings. These results seem to be consistent with the family investment hypothesis proposed by Benjamin and Baker (200?), where they indicates that female immigrants often 
take on dead-end jobs to support their husbands' initial investment in acquiring local human capital. In addition, speaking French fluently has positive and significant effect on male but not female's earnings and this difference is mainly due to lack of variation for female sample. Only 6 per cent of the female sample do not speak French fluently, whereas this ratio for male sample is 13 per cent. To have no religion is never significant in earnings equation, both for males and females. Being African is associated with lower earnings, especially for males, while Asians receive higher earnings related to their Turkish counterparts.

Turning to our main interest of intermarriage premia, we find that without controlling for possible endogeneity problem, intermarried immigrants on average earn 6.2 per cent more than their endogamously married counterparts, ceteris paribus. Women gain more out of intermarriage than men (9.3 per cent vs 5.2 per cent) and both are statistically significant. The IV estimation handles the possibility of reverse causality between intermarriage and earnings and uses the linear probability model as the first stage estimation. Once controlling for the endogeneity issue, the estimated intermarriage premium increased for all samples. For the total sample, we observe a 24 per cent hourly earnings gain from intermarriage, while for female and male samples the premium is 76 and 15 per cent, respectively. The point estimate for male sample, however, is not statistically significant. This indicates that perhaps, our instrumental variables are not generating enough variations to identify intermarriage equation from the earnings equation for the male sample. Indeed, once the probit model is used as the first stage estimation, where the non-linear functional form provides additional variations to the purged intermarriage variable, the effect for all samples become statistically significant at the 1 per cent level. With the two-stage estimation, intermarriage premium for the total sample is 36 per cent, for female and male samples it is 94 and 27 per cent, respectively.

Note that the reason we are worried about the endogeneity of intermarriage in the earnings equation is because there may be unobservable characteristics which make individuals to intermarry at the same time to earn higher or lower earnings than their endogamously married counterparts. Controlling for such an endogeneity, we find an increase in intermarriage premium, suggesting that the unobservable characteristics which make an individual intermarry contribute negatively to his/her earnings. This finding is consistent with Meng and Gregory 
(2005) for the Australia case, but at odds with Kantarevic's (2005) finding that once control for endogeneity the intermarriage premium for the US immigrants disappears.

Like Meng and Gregory (2005) we also find that once endogenise intermarriage, the intermarriage premium becomes unbelievably high. The reason for such a large change in the magnitude of coefficient may be two fold. The first reason is related to sample selection bias. As we only observe earnings for wage and salary earners, there is a serious sample selection problem for women. To test if the sample selection bias caused the sharp increase in the magnitude of the intermarriage coefficient, we follow Woolridge (2002) procedure and estimated the sample selection for endogenous explanatory variable model for our female sample (Woolridge, 2002, pp.567). The instrumental variables used are sex ratio, probability of marry within, number of children aged 0 to 6 and total number of children. The results are presented in Table 6 . It shows that controlling for sample selection results in an increase in the estimated coefficients on intermarriage, suggesting that those who are not in the labour force may be more likely to intermarry and also had they been working they would have earned a higher earnings relative to those who are currently working. This conjecture is also consistent with the fact that for IV and two stage estimations the inverse Mill's ratio is positive and statistically significant. This result may be reasonable if we extend the family investment hypothesis to take into account that if more able immigrants also under less credit constraint, and hence less likely to be in a hurry to take on any job comes to their way.

The second reason may be related to the small sample size. We only have 557 observations

for the female sample and perhaps the instruments are not strong enough to produce stable results. Although we are not able to resolve this problem, knowing that the OLS produces a higher intermarriage premium for women than for men is reassuring.

\subsection{Language and intermarriage premium}

Intermarriage facilitate economic assimilation of immigrants through the following possible channels: improvement in the native language skill and acquisition of the local labour market knowledge. In this sub-section we try to untangle the two effects by estimating the intermarriage premium for the African and non-African samples, separately. As discussed before most 
Africans in our sample come from countries where French is used as the official language or is used to teach all the disciplines at school. Thus, African immigrants have very good grasp of French language before they immigrate to France. For example 80 per cent of our African sample indicated that they speaks French before migration, while only 52 per cent of the non-African fall into this category.

Equation (1) is estimated using the three different procedures for the African and nonAfrican samples and the results are presented in Table 7. In addition to intermarriage effect, the most obvious difference between the results for the two groups are the following. The gender earnings gap is higher for non-African sample, and the rate of return to above secondary education is also much higher for this group than for the African sample. Those who have no religion earn more if they are Africans but this variable is statistically insignificant for non-African sample. Most importantly, intermarriage premium is much higher for African immigrants than for non-African immigrants. In the OLS estimation the intermarriage premium for African is 11 per cent while for non-African is 4 per cent and statistically insignificant. The IV estimate raises the premium for Africans to 31 per cent and for non-African to 14 per cent and still not statistically significant. Finally, the two-stage estimation generated a 35 per cent intermarriage premium for Africans and 29 per cent for non-Africans and they are both statistically significant.

It is interesting that intermarriage actually bring much higher premium to Africans. Suppose that intermarriage facilitate language improvement and acquisition of local labour market knowledge, then those with less room for language improvement should benefit less from intermarriage than those who have more room for language improvement. The fact that we find African people are gaining more from intermarriage is somewhat puzzling. There are two possible explanations. First, perhaps African are more likely to be discriminated against relative to their non-African immigrant counterparts and once an African marry a white person, the market discrimination will reduce, and hence, relative to non-Africans the intermarriage premium for African is higher. Second, perhaps better language skills enable immigrants to better use the local labour market knowledge and networks, which in turn enables them to gain higher earnings. 
To test which of these two hypotheses are more plausible, we perform two additional exercises. First, we estimate intermarriage premium for African immigrants who spoke French before migration and currently speak French fluently according to interviewers. If the language hypothesis is right, we should observe a higher intermarriage premium for those whose language skill are better. Otherwise, the discrimination hypothesis should predict that the intermarriage premia is the same for both African with or without better language skills. The results of this exercise are also presented in Table 7 (second columns in each panel). The results show that those Africans who spoke French before migration and currently speak French fluently gaining even more from intermarriage than the average African sample. The OLS estimation show that the intermarriage premium for this group is 11 per cent, which is slightly higher than the premium for the total African sample. The IV and two-stage estimates result in much higher intermarriage premia for Africans with good French ability than for the total African sample. The difference for the two samples using IV estimation is 18 per cent while for using two-stage estimation is 14 per cent. This exercise seems to be consistent with the hypothesis that better language skills facilitate intermarried immigrants to gain more out of the intermarriage.

The second exercise is to estimate equation (1) for immigrants who spoke French before migration and those who did not separately and compare their intermarriage premia. If intermarriage premium is higher for the group with better language skill, then this may further confirm our language skill hypothesis. The results for this sub-sample are presented in Table 8. Once again we show that for those who spoke French before migration the intermarriage premium is much higher than for those who did not speak French before migration.

Both additional exercises seem to indicate that better pre-acquisition of language facilitate better utilisation of the local labour market knowledge obtained from the native partners.

\section{Conclusions}

In this paper we examined the effect of intermarriage in the process of economic assimilation of immigrants in France. We found that like in many other countries, immigrants in France who intermarry earn around 6 to 10 per cent higher earnings than their endogamously married 
counterparts controlling for individual characteristics. This intermarriage premium increases significantly when intermarriage is treated as an endogenous variable.

The paper further investigated the extent to which intermarriage premia observed are due to better information on local labour market situation. By comparing immigrants from formal colonial African countries where French is either official language or used since primary school with immigrants from non-African countries we found that intermarried African immigrants gain more out of intermarriage than their non-African counterparts. This result indicates that immigrants with better language skill can reap more gain from learning local labour market knowledge from their native partners. 


\section{References}

[1] Angrist, Josh, 2002, "How do sex ratios affect marriage and labor markets? Evidence from America's second generation" Quarterly Journal of Economics, 117 (3), pp. 997-1038.

[2] Bell, Brian D., 1997, "The performance of immigrants in the United Kingdom: evidence from the GHS", The Economic Journal, 107(441), pp. 333-344.

[3] Baker, Michael and Dwayne Benjamin, 1994, "The performance of immigrants in the Canadian labor market", Journal of Labor Economics, 12(3), 369-405.

[4] Borjas, George J., 1985, "Assimilation, changes in cohort quality, and the earnings of immigrants", Journal of Labor Economics, 3, pp.463-489.

[5] Borjas, George J., 1995, "Assimilation and changes in cohort quality revisited: what happened to immigrant earnings in the 1980s?", Journal of Labor Economics, 13(2), pp.201245 .

[6] Borrel, Catherine and Tavan Chloé, 2003, La vie familiale des immigrés, in French, Portrait social, INSEE.

[7] Chiswick, Barry R., 1978, "The effect of Americanization on the earnings of foreign-born men", Journal of Political Economy, 86(5), pp.897-921.

[8] Chiswick, Barry R. and Paul W. Miller, 1995, "The endogeneity between language and earnings: international analyses", Journal of Labor Economics, 13(2), pp.246-288.

[9] Constant, Amelie, 2003, "Immigrant adjustment in France and impacts on the natives", IZA, discussion paper no. 866, August.

[10] Dayan, Jean-Louis, Echardour Annick, and Glaude Michel, 1996, "Le parcours professionnel des immigrants en France : une analyse longitudinale", Economie et statistiques, no. 299, pp. 107-128.

[11] Dupray Arnaud, and Moullet Stéphanie., "Quelles discriminations à l'encontre des jeunes d'origine maghérébine à l'entrée du marché du travail en France", working paper, avril 2003.

[12] Dustmann, Christian and Van Soest Arthur 2002, "Language and the earnings of immigrants", Industrial and Labor Relations Review, 55(3), 473-492 
[13] Dustmann, Christian and Fabbri Francesca, "Language proficiency and labour market performance of immigrants in the UK", The Economic Journal, 113 (July), 695-717

[14] Fournier, Irène, Silberman Roxane , 1999, "Les enfants d'immigrants sur le marché du travail. Les mécanismes d'une discrimination sélective", Formation emploi, no. 65.

[15] Kantarevic, Jasmin, 2004, "Interethnic marriages and economic assimilation of migrants", IZA discussion paper, no. 1142, May

[16] Lazear, Edward, 1999, "Culture and language", Journal of Political Economy, 107, pp 95-129

[17] Maurin, Eric, 1991, "Les étrangers : une main d'œuvre à part ?", Economie et Statistique, $\mathrm{n}^{\circ} 242$, p.39-50.

[18] Meng, Xin and Robert G. Gregory, 2005, "Intermarriage and economic assimilation of immigrants", Journal of Labor Economics, 23(1), pp.135-176.

[19] Meurs, Dominique, Pailhé Ariane, Simon Patrick., 2005, "Mobilité intergénérationnelle et persistance des inégalités : l'accès à l'emploi des immigrés et de leurs descendants en France", sept, working paper INED/ ERMES.

[20] Qian, Zenchao, 1999, "Who intermarries? education, nationality, region and interracial marriage, 1980, 1990", Journal of Comparative Family Studies, 30(4), 579-597.

[21] Qian, Zenchao, Lichter Daniel T, 2001, "Measuring marital assimilation : intermarriage among natives and immigrants", Social Science Research, 30, 289-312

[22] Tribalat, Michele., Simon Patrick., Riandey Benoit., 1996, De l'immigration à l'assimilation. Enquête sur les populations étrangères en France, Paris, INED/La Découverte. 
Figure 1: Immigration flow by entry visa categories and by gender Panel 1: Males immigrants
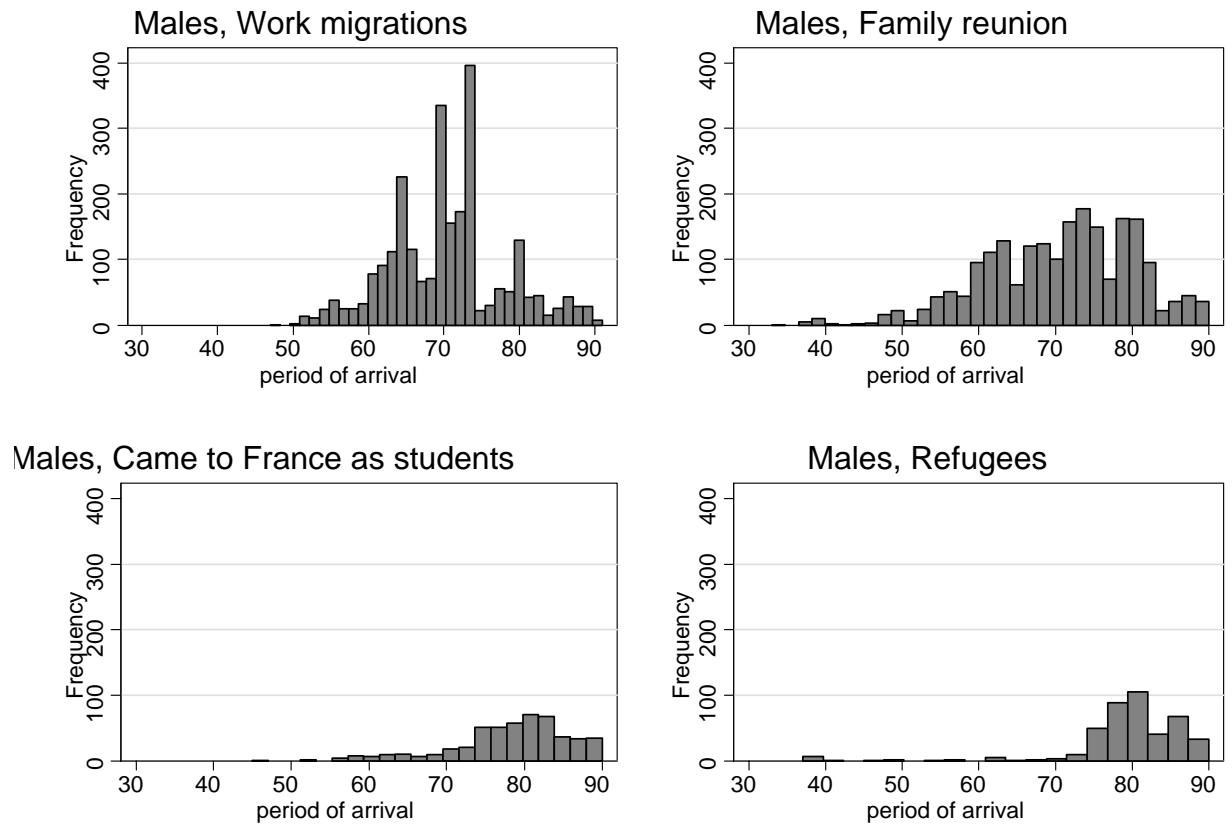

Panel 2: Female immigrants

Females, Work migrations

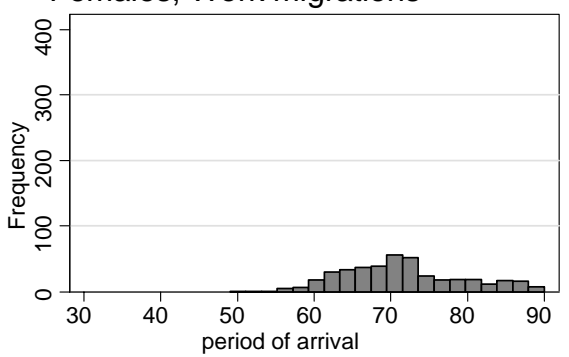

!males, Came to France as students

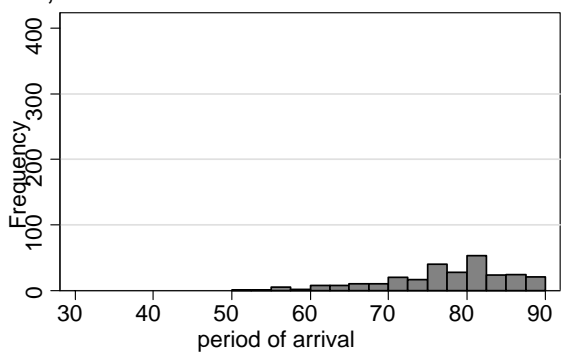

Females, Family reunion

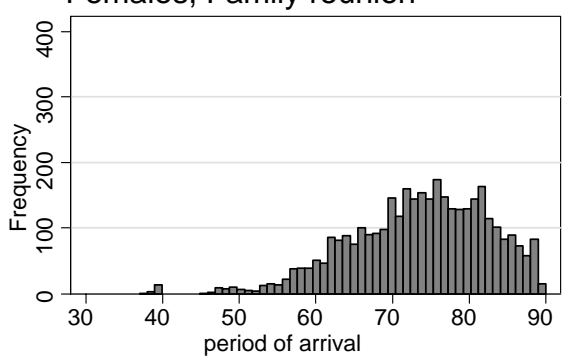

Females, Refugees

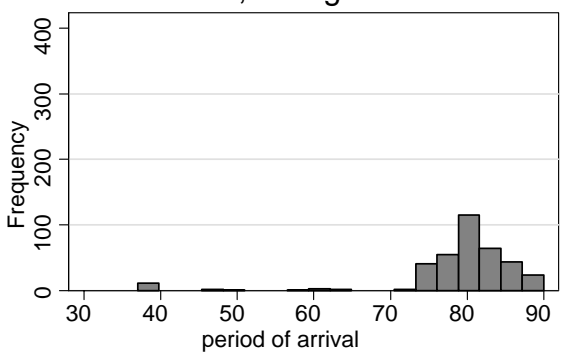


Table 1: Composition of French population

\begin{tabular}{|c|c|c|c|}
\hline & $\begin{array}{l}\text { Population } \\
\text { frequency }\end{array}$ & $\begin{array}{l}\text { As } \% \text { of immigrant } \\
\text { population }\end{array}$ & $\begin{array}{l}\text { As \% of total } \\
\text { population }\end{array}$ \\
\hline Total of population in France & 58518395 & & \\
\hline Total immigrant population & $4,306,094$ & & 7.36 \\
\hline Country of Origin: & & & \\
\hline Europe & 1934144 & 45.0 & 3.31 \\
\hline Spain & 316232 & 7.4 & 0.54 \\
\hline Italy & 378649 & 8.8 & 0.65 \\
\hline Portugal & 571874 & 13.3 & 0.98 \\
\hline Poland & 98571 & 2.3 & 0.17 \\
\hline Other & 568818 & 13.2 & 0.97 \\
\hline Africa & 1691562 & 39.3 & 2.89 \\
\hline Algeria & 574208 & 13.4 & 0.98 \\
\hline Morocco & 522504 & 12.1 & 0.89 \\
\hline Tunisia & 202561 & 4.7 & 0.35 \\
\hline Other & 393289 & 9.1 & 0.67 \\
\hline Asia & 549994 & 12.7 & 0.94 \\
\hline Turkey & 171160 & 4.0 & 0.29 \\
\hline Cambodge, Laos, Vietnam & 159750 & 3.7 & 0.27 \\
\hline Other & 216084 & 5.0 & 0.37 \\
\hline Amerique, Oceanie & 130394 & 3.0 & 0.22 \\
\hline
\end{tabular}


Table 2: Summary statistics of the full sample and sample used in this study

\begin{tabular}{|c|c|c|c|c|c|c|}
\hline \multicolumn{7}{|l|}{ Full sample } \\
\hline & \multirow[t]{2}{*}{ Total } & \multicolumn{2}{|c|}{ Females } & \multicolumn{2}{|r|}{ Africans } & Non africans \\
\hline & & 0.54 & & & 0.57 & 0.52 \\
\hline intermarriage rate & & 0.14 & 0.13 & 0.17 & 0.12 & 0.18 \\
\hline age & & 38.32 & 37.21 & 39.27 & 38.74 & 38.00 \\
\hline years since migration & & 19.09 & 17.72 & 20.26 & 18.20 & 19.78 \\
\hline secondary education & & 0.56 & 0.54 & 0.58 & 0.48 & 0.62 \\
\hline above secondary education & & 0.08 & 0.10 & 0.06 & 0.13 & 0.04 \\
\hline french good & & 0.70 & 0.66 & 0.74 & 0.70 & 0.71 \\
\hline french spoken before migration & & 0.52 & 0.48 & 0.55 & 0.67 & 0.40 \\
\hline no religious belief & & 0.36 & 0.31 & 0.41 & 0.36 & 0.37 \\
\hline paris & & 0.29 & 0.28 & 0.30 & 0.34 & 0.25 \\
\hline asia & & 0.43 & 0.09 & 0.08 & & \\
\hline africa & & 0.08 & 0.41 & 0.46 & & 0.14 \\
\hline europ & & 0.30 & 0.33 & 0.28 & & 0.54 \\
\hline participation to the labour market & & 0.74 & 0.57 & 0.89 & 0.71 & 0.76 \\
\hline Obs. & & 8893 & 4082 & 4811 & 3863 & 5030 \\
\hline \multicolumn{7}{|c|}{ Sample used in the study (wae and salary earners married after migration) } \\
\hline \multirow[t]{2}{*}{ Variable } & \multirow[t]{2}{*}{ Total } & \multirow{2}{*}{\multicolumn{2}{|c|}{${ }_{0.75}$ Females Males }} & \multicolumn{2}{|r|}{ Africans } & Non africans \\
\hline & & & & & 0.85 & 0.69 \\
\hline intermarriage & & 0.34 & 0.39 & 0.33 & 0.29 & 0.37 \\
\hline age & & 37.84 & 35.28 & 38.70 & 39.79 & 36.83 \\
\hline years since migration & & 22.48 & 23.06 & 22.29 & 21.42 & 23.03 \\
\hline secondary education & & 0.41 & 0.50 & 0.38 & 0.58 & 0.75 \\
\hline above secondary education & & 0.23 & 0.24 & 0.22 & 0.17 & 0.05 \\
\hline french good & & 0.88 & 0.94 & 0.87 & 0.86 & 0.90 \\
\hline french spoken before migration & & 0.62 & 0.66 & 0.61 & 0.80 & 0.53 \\
\hline no religious belief & & 0.44 & 0.37 & 0.46 & 0.46 & 0.42 \\
\hline paris & & 0.30 & 0.33 & 0.29 & 0.35 & 0.28 \\
\hline afr & & 0.34 & 0.20 & 0.39 & 1.00 & 0.00 \\
\hline asia & & 0.07 & 0.08 & 0.07 & & 0.11 \\
\hline europ & & 0.46 & 0.65 & 0.40 & & 0.70 \\
\hline obs & & 2222 & 557 & 1665 & 760 & 1462 \\
\hline
\end{tabular}


Table 3: Determinants of Intermarriage

\begin{tabular}{|c|c|c|c|c|c|c|c|c|c|c|c|c|}
\hline & \multicolumn{6}{|c|}{ Total sample } & \multicolumn{6}{|c|}{ Separate sample for Africans and non-Africans } \\
\hline & \multicolumn{3}{|c|}{ Linear Probability Model } & \multicolumn{3}{|c|}{ Probit (Marginal Effects) } & \multicolumn{3}{|c|}{ Probit (Margianl Effects) Africans } & \multicolumn{3}{|c|}{ Probit (Margianl Effects) non-Africans } \\
\hline Males & $\begin{array}{l}\text { Total } \\
0.057 \\
(0.016)^{\star \star *}\end{array}$ & Females & Males & $\begin{array}{l}\text { Total } \\
0.068 \\
(0.018)^{\star \star \star}\end{array}$ & Females & Males & $\begin{array}{l}\text { Total } \\
0.131 \\
(0.028)^{\star \star \star}\end{array}$ & Females & Males & $\begin{array}{l}\text { Total } \\
0.041 \\
(0.023)^{\star}\end{array}$ & Females & Males \\
\hline Sex ratio & $\begin{array}{l}-0.162 \\
(0.030)^{\star \star \star}\end{array}$ & $\begin{array}{l}-0.212 \\
(0.065)^{\star \star \star}\end{array}$ & $\begin{array}{l}-0.146 \\
(0.034)^{\star \star \star}\end{array}$ & $\begin{array}{l}-0.204 \\
(0.039)^{\star \star \star}\end{array}$ & $\begin{array}{l}-0.278 \\
(0.087)^{\star \star \star}\end{array}$ & $\begin{array}{l}-0.171 \\
(0.043)^{\star \star \star}\end{array}$ & $\begin{array}{l}-0.226 \\
(0.062)^{\star \star \star}\end{array}$ & $\begin{array}{l}-0.359 \\
(0.175)^{\star \star}\end{array}$ & $\begin{array}{l}-0.192 \\
(0.072)^{\star \star \star}\end{array}$ & $\begin{array}{l}-0.173 \\
(0.056)^{\star \star \star}\end{array}$ & $\begin{array}{l}-0.255 \\
(0.108)^{\star \star}\end{array}$ & $\begin{array}{l}-0.1 \\
-0.07\end{array}$ \\
\hline Probability of marry within & $\begin{array}{l}-2.932 \\
(0.422)^{\star \star \star}\end{array}$ & $\begin{array}{l}-4.668 \\
(0.903)^{\star \star \star}\end{array}$ & $\begin{array}{l}-2.556 \\
(0.466)^{\star \star \star}\end{array}$ & $\begin{array}{l}-3.647 \\
(0.707)^{\star \star \star}\end{array}$ & $\begin{array}{l}-5.925 \\
(1.353)^{\star \star \star}\end{array}$ & $\begin{array}{l}-3.043 \\
(0.742)^{\star \star \star}\end{array}$ & $\begin{array}{l}-1.578 \\
(0.701)^{\star \star}\end{array}$ & $\begin{array}{l}-4.757 \\
(2.169)^{\star \star}\end{array}$ & $\begin{array}{l}-1.471 \\
(0.730)^{\star \star}\end{array}$ & $\begin{array}{l}-7.088 \\
(1.050)^{\star \star \star}\end{array}$ & $\begin{array}{l}-7.773 \\
(1.718)^{\star \star \star}\end{array}$ & $\begin{array}{l}-6.063 \\
(1.354)^{\star \star \star}\end{array}$ \\
\hline Age & $\begin{array}{l}0.01 \\
(0.005)^{\star}\end{array}$ & $\begin{array}{l}0.013 \\
(0.01)\end{array}$ & $\begin{array}{l}0.002 \\
(0.007)\end{array}$ & $\begin{array}{l}0.011 \\
(0.007)\end{array}$ & $\begin{array}{l}0.022 \\
(0.013)^{\star}\end{array}$ & $\begin{array}{l}0.001 \\
(0.009)\end{array}$ & $\begin{array}{l}-0.022 \\
(0.012)^{\star}\end{array}$ & $\begin{array}{l}-0.019 \\
(0.031)\end{array}$ & $\begin{array}{l}-0.049 \\
(0.016)^{\star \star \star}\end{array}$ & $\begin{array}{l}0.034 \\
(0.009)^{\star \star \star}\end{array}$ & $\begin{array}{l}0.034 \\
(0.016)^{\star \star}\end{array}$ & $\begin{array}{l}0.034 \\
(0.012)^{\star \star \star}\end{array}$ \\
\hline $\mathrm{Age}^{2}$ & $\begin{array}{l}-0.02 \\
(0.007)^{\star \star \star}\end{array}$ & $\begin{array}{l}-0.015 \\
(0.013)\end{array}$ & $\begin{array}{l}-0.015 \\
(0.008)^{\star}\end{array}$ & $\begin{array}{l}-0.021 \\
(0.009)^{\star \star}\end{array}$ & $\begin{array}{l}-0.024 \\
(0.016)\end{array}$ & $\begin{array}{l}-0.013 \\
(0.011)\end{array}$ & $\begin{array}{l}0.019 \\
(0.015)\end{array}$ & $\begin{array}{l}0.039 \\
(0.046)\end{array}$ & $\begin{array}{l}0.049 \\
(0.019)^{\star \star}\end{array}$ & $\begin{array}{l}-0.052 \\
(0.012)^{\star \star \star}\end{array}$ & $\begin{array}{l}-0.046 \\
(0.020)^{\star \star}\end{array}$ & $\begin{array}{l}-0.056 \\
(0.015)^{\star \star \star}\end{array}$ \\
\hline Secondary education & $\begin{array}{l}0.091 \\
(0.018)^{\star \star \star}\end{array}$ & $\begin{array}{l}0.079 \\
(0.035)^{\star *}\end{array}$ & $\begin{array}{l}0.086 \\
(0.022)^{\star \star \star}\end{array}$ & $\begin{array}{l}0.12 \\
(0.023)^{\star \star *}\end{array}$ & $\begin{array}{l}0.119 \\
(0.042)^{\star \star \star}\end{array}$ & $\begin{array}{l}0.113 \\
(0.027)^{\star \star \star}\end{array}$ & $\begin{array}{l}0.123 \\
(0.037)^{\star \star \star}\end{array}$ & $\begin{array}{l}0.155 \\
(0.086)^{\star}\end{array}$ & $\begin{array}{l}0.111 \\
(0.043)^{\star \star \star}\end{array}$ & $\begin{array}{l}0.088 \\
(0.031)^{\star \star \star}\end{array}$ & $\begin{array}{l}0.097 \\
(0.052)^{\star}\end{array}$ & $\begin{array}{l}0.081 \\
(0.037)^{\star \star}\end{array}$ \\
\hline Above Secondary education & $\begin{array}{l}0.314 \\
(0.033)^{\star \star \star}\end{array}$ & $\begin{array}{l}0.255 \\
(0.065)^{\star \star \star}\end{array}$ & $\begin{array}{l}0.31 \\
(0.039)^{\star \star \star}\end{array}$ & $\begin{array}{l}0.386 \\
(0.040)^{\star \star \star}\end{array}$ & $\begin{array}{l}0.356 \\
(0.085)^{\star \star \star}\end{array}$ & $\begin{array}{l}0.374 \\
(0.047)^{\star \star \star}\end{array}$ & $\begin{array}{l}0.363 \\
(0.058)^{\star \star \star}\end{array}$ & $\begin{array}{l}0.278 \\
(0.153)^{\star}\end{array}$ & $\begin{array}{l}0.372 \\
(0.066)^{\star \star \star}\end{array}$ & $\begin{array}{l}0.224 \\
(0.073)^{\star \star \star}\end{array}$ & $\begin{array}{l}0.38 \\
(0.117)^{\star \star \star}\end{array}$ & $\begin{array}{l}0.126 \\
-0.09\end{array}$ \\
\hline Year since migration & $\begin{array}{l}0.01 \\
(0.001)^{\star \star \star}\end{array}$ & $\begin{array}{l}0.008 \\
(0.002)^{\star \star \star}\end{array}$ & $\begin{array}{l}0.011 \\
(0.002)^{\star \star \star}\end{array}$ & $\begin{array}{l}0.01 \\
(0.002)^{\star \star \star}\end{array}$ & $\begin{array}{l}0.007 \\
(0.003)^{\star \star}\end{array}$ & $\begin{array}{l}0.011 \\
(0.002)^{\star \star \star}\end{array}$ & $\begin{array}{l}0.003 \\
-0.002\end{array}$ & $\begin{array}{l}-0.001 \\
-0.004\end{array}$ & $\begin{array}{l}0.004 \\
(0.002)^{\star}\end{array}$ & $\begin{array}{l}0.019 \\
(0.003)^{\star \star \star}\end{array}$ & $\begin{array}{l}0.016 \\
(0.004)^{\star \star \star}\end{array}$ & $\begin{array}{l}0.02 \\
(0.003)^{\star \star \star}\end{array}$ \\
\hline French fluent & $\begin{array}{l}0.041 \\
(0.018)^{\star \star}\end{array}$ & $\begin{array}{l}0.084 \\
(0.030)^{\star \star \star}\end{array}$ & $\begin{array}{l}0.022 \\
-0.023\end{array}$ & $\begin{array}{l}0.106 \\
(0.028)^{\star \star \star}\end{array}$ & $\begin{array}{l}0.255 \\
(0.035)^{\star \star \star}\end{array}$ & $\begin{array}{l}0.064 \\
(0.034)^{\star}\end{array}$ & $\begin{array}{l}0.082 \\
(0.041)^{\star \star}\end{array}$ & & $\begin{array}{l}0.052 \\
-0.049\end{array}$ & $\begin{array}{l}0.117 \\
(0.039)^{\star \star \star}\end{array}$ & $\begin{array}{l}0.253 \\
(0.055)^{\star \star \star}\end{array}$ & $\begin{array}{l}0.067 \\
-0.048\end{array}$ \\
\hline French before migration & $\begin{array}{l}0.093 \\
(0.018)^{\star \star \star}\end{array}$ & $\begin{array}{l}0.128 \\
(0.031)^{\star \star \star}\end{array}$ & $\begin{array}{l}0.074 \\
(0.023)^{\star \star \star}\end{array}$ & $\begin{array}{l}0.098 \\
(0.022)^{\star \star \star}\end{array}$ & $\begin{array}{l}0.142 \\
(0.037)^{\star \star \star}\end{array}$ & $\begin{array}{l}0.074 \\
(0.027)^{\star \star \star}\end{array}$ & $\begin{array}{l}0.073 \\
(0.037)^{\star \star}\end{array}$ & $\begin{array}{l}0.07 \\
(0.084)\end{array}$ & $\begin{array}{l}0.074 \\
(0.043)^{\star}\end{array}$ & $\begin{array}{l}0.085 \\
(0.030)^{\star \star *}\end{array}$ & $\begin{array}{l}0.112 \\
(0.048)^{\star \star}\end{array}$ & $\begin{array}{l}0.063 \\
-0.039\end{array}$ \\
\hline No religious belief & $\begin{array}{l}0.131 \\
(0.015)^{\star \star \star}\end{array}$ & $\begin{array}{l}0.09 \\
(0.025)^{\star \star \star}\end{array}$ & $\begin{array}{l}0.158 \\
(0.018)^{\star \star \star}\end{array}$ & $\begin{array}{l}0.151 \\
(0.017)^{\star \star \star}\end{array}$ & $\begin{array}{l}0.098 \\
(0.030)^{\star \star \star}\end{array}$ & $\begin{array}{l}0.181 \\
(0.020)^{\star \star \star}\end{array}$ & $\begin{array}{l}0.13 \\
(0.025)^{\star \star \star}\end{array}$ & $\begin{array}{l}0.036 \\
-0.052\end{array}$ & $\begin{array}{l}0.166 \\
(0.030)^{\star \star \star}\end{array}$ & $\begin{array}{l}0.17 \\
(0.023)^{\star \star \star}\end{array}$ & $\begin{array}{l}0.122 \\
(0.039)^{\star \star \star}\end{array}$ & $\begin{array}{l}0.204 \\
(0.028)^{\star \star \star}\end{array}$ \\
\hline Paris & $\begin{array}{l}-0.065 \\
(0.017)^{\star \star \star}\end{array}$ & $\begin{array}{l}-0.067 \\
(0.029)^{\star \star}\end{array}$ & $\begin{array}{l}-0.061 \\
(0.021)^{\star \star \star}\end{array}$ & $\begin{array}{l}-0.062 \\
(0.020)^{\star \star \star}\end{array}$ & $\begin{array}{l}-0.071 \\
(0.035)^{\star \star}\end{array}$ & $\begin{array}{l}-0.058 \\
(0.025)^{\star \star}\end{array}$ & $\begin{array}{l}-0.01 \\
-0.029\end{array}$ & $\begin{array}{l}0.045 \\
(0.066)\end{array}$ & $\begin{array}{l}-0.017 \\
-0.034\end{array}$ & $\begin{array}{l}-0.081 \\
(0.026)^{\star \star \star}\end{array}$ & $\begin{array}{l}-0.124 \\
(0.042)^{\star \star \star}\end{array}$ & $\begin{array}{l}-0.073 \\
(0.035)^{\star \star}\end{array}$ \\
\hline Africans & $\begin{array}{l}0.176 \\
(0.024)^{\star \star *}\end{array}$ & $\begin{array}{l}0.155 \\
(0.038)^{\star \star \star}\end{array}$ & $\begin{array}{l}0.201 \\
(0.030)^{\star \star \star}\end{array}$ & $\begin{array}{l}0.27 \\
(0.038)^{\star \star *}\end{array}$ & $\begin{array}{l}0.289 \\
(0.083)^{\star \star \star}\end{array}$ & $\begin{array}{l}0.284 \\
(0.044)^{\star \star \star}\end{array}$ & & & & & & \\
\hline Asians & $\begin{array}{l}0.111 \\
(0.030)^{\star \star \star}\end{array}$ & $\begin{array}{l}0.092 \\
(0.042)^{\star \star}\end{array}$ & $\begin{array}{l}0.131 \\
(0.042)^{\star \star \star}\end{array}$ & $\begin{array}{l}0.205 \\
(0.052)^{\star \star \star}\end{array}$ & $\begin{array}{l}0.186 \\
(0.105)^{\star}\end{array}$ & $\begin{array}{l}0.234 \\
(0.063)^{\star \star \star}\end{array}$ & & & & $\begin{array}{l}0.217 \\
(0.054)^{\star \star \star}\end{array}$ & $\begin{array}{l}0.207 \\
(0.107)^{\star}\end{array}$ & $\begin{array}{l}0.25 \\
(0.065)^{\star \star \star}\end{array}$ \\
\hline Europeans & $\begin{array}{l}0.327 \\
(0.023)^{\star \star \star}\end{array}$ & $\begin{array}{l}0.342 \\
(0.039)^{\star \star \star}\end{array}$ & $\begin{array}{l}0.312 \\
(0.029)^{\star \star \star}\end{array}$ & $\begin{array}{l}0.413 \\
(0.034)^{\star \star \star}\end{array}$ & $\begin{array}{l}0.432 \\
(0.061)^{\star \star \star}\end{array}$ & $\begin{array}{l}0.399 \\
(0.041)^{\star \star \star}\end{array}$ & & & & $\begin{array}{l}0.301 \\
(0.030)^{\star \star \star}\end{array}$ & $\begin{array}{l}0.362 \\
(0.052)^{\star \star \star}\end{array}$ & $\begin{array}{l}0.267 \\
(0.038)^{\star \star \star}\end{array}$ \\
\hline Observations & 3685 & 1263 & 2422 & 3685 & 1263 & 2422 & 1328 & 301 & 992 & 2357 & 927 & 1430 \\
\hline $\mathrm{R}^{2} /$ Pseudo $\mathrm{R}^{2}$ & 0.23 & 0.26 & 0.23 & 0.21 & 0.24 & 0.2 & 0.14 & 0.05 & 0.17 & 0.26 & 0.29 & 0.26 \\
\hline
\end{tabular}

Robust standard errors in parentheses

* significant at $10 \%$; ** significant at $5 \%$; *** significant at $1 \%$ 
Table 4: Labour force participation of women

\begin{tabular}{|c|c|c|c|c|}
\hline & LPM & $\begin{array}{l}\text { Sample } \\
\text { Probit (Marginal } \\
\text { Effects) }\end{array}$ & $\begin{array}{c}\text { Africans } \\
\text { Probit (Marginal } \\
\text { Effects) }\end{array}$ & $\begin{array}{c}\text { Non-Africans } \\
\text { Probit (Marginal } \\
\text { Effects) }\end{array}$ \\
\hline Number of children aged 0-6 & $\begin{array}{l}-0.121 \\
(0.020)^{\star \star \star}\end{array}$ & $\begin{array}{l}-0.12 \\
(0.020)^{\star \star \star}\end{array}$ & $\begin{array}{l}-0.091 \\
(0.037)^{\star \star}\end{array}$ & $\begin{array}{l}-0.135 \\
(0.025)^{\star \star \star}\end{array}$ \\
\hline Number of children aged $0-6$ & $\begin{array}{l}-0.048 \\
(0.012)^{\star \star \star}\end{array}$ & $\begin{array}{l}-0.047 \\
(0.012)^{\star \star \star}\end{array}$ & $\begin{array}{l}-0.041 \\
(0.019)^{\star \star}\end{array}$ & $\begin{array}{l}-0.062 \\
(0.016)^{\star \star \star}\end{array}$ \\
\hline Intermarriage & $\begin{array}{l}-0.005 \\
(0.028)\end{array}$ & $\begin{array}{l}-0.005 \\
(0.031)\end{array}$ & $\begin{array}{l}0.085 \\
(0.061)\end{array}$ & $\begin{array}{l}-0.041 \\
(0.037)\end{array}$ \\
\hline Age & $\begin{array}{l}0.038 \\
(0.011)^{\star \star \star}\end{array}$ & $\begin{array}{l}0.035 \\
(0.011)^{\star \star \star}\end{array}$ & $\begin{array}{l}0.054 \\
(0.023)^{\star \star}\end{array}$ & $\begin{array}{l}0.02 \\
(0.013)\end{array}$ \\
\hline $\mathrm{Age}^{2}$ & $\begin{array}{l}-0.053 \\
(0.014)^{\star \star \star *}\end{array}$ & $\begin{array}{l}-0.051 \\
(0.014)^{\star \star \star}\end{array}$ & $\begin{array}{l}-0.062 \\
(0.032)^{\star}\end{array}$ & $\begin{array}{l}-0.037 \\
(0.016)^{\star \star}\end{array}$ \\
\hline Secondary education & $\begin{array}{l}0.04 \\
(0.040)\end{array}$ & $\begin{array}{l}0.04 \\
(0.043)\end{array}$ & $\begin{array}{l}-0.04 \\
(0.096)\end{array}$ & $\begin{array}{l}0.068 \\
(0.049)\end{array}$ \\
\hline Above secondary education & $\begin{array}{l}0.027 \\
(0.067)\end{array}$ & $\begin{array}{l}0.02 \\
(0.069)\end{array}$ & $\begin{array}{l}-0.042 \\
(0.128)\end{array}$ & $\begin{array}{l}0.005 \\
(0.098)\end{array}$ \\
\hline Year since migration & $\begin{array}{l}-0.002 \\
(0.002)\end{array}$ & $\begin{array}{l}-0.002 \\
(0.003)\end{array}$ & $\begin{array}{l}-0.005 \\
(0.004)\end{array}$ & $\begin{array}{l}0.001 \\
(0.003)\end{array}$ \\
\hline No religion belief & $\begin{array}{l}0.026 \\
(0.026)\end{array}$ & $\begin{array}{l}0.024 \\
(0.027)\end{array}$ & $\begin{array}{l}0.063 \\
(0.053)\end{array}$ & $\begin{array}{l}0.012 \\
(0.031)\end{array}$ \\
\hline Speak French fluently & $\begin{array}{l}0.007 \\
(0.049)\end{array}$ & $\begin{array}{l}0.002 \\
(0.048)\end{array}$ & $\begin{array}{l}0.078 \\
(0.120)\end{array}$ & $\begin{array}{l}-0.008 \\
(0.054)\end{array}$ \\
\hline Speak French before migration & $\begin{array}{l}0.009 \\
(0.034)\end{array}$ & $\begin{array}{l}0.009 \\
(0.036)\end{array}$ & $\begin{array}{l}0.036 \\
(0.083)\end{array}$ & $\begin{array}{l}-0.031 \\
(0.041)\end{array}$ \\
\hline Paris & $\begin{array}{l}0.069 \\
(0.027)^{\star \star}\end{array}$ & $\begin{array}{l}0.073 \\
(0.029)^{\star \star}\end{array}$ & $\begin{array}{l}0.124 \\
(0.055)^{\star \star}\end{array}$ & $\begin{array}{l}0.054 \\
(0.034)\end{array}$ \\
\hline African & $\begin{array}{l}-0.008 \\
(0.054)\end{array}$ & $\begin{array}{l}-0.004 \\
(0.054)\end{array}$ & & \\
\hline Asian & $\begin{array}{l}-0.051 \\
(0.060)\end{array}$ & $\begin{array}{l}-0.048 \\
(0.063)\end{array}$ & & $\begin{array}{l}-0.004 \\
(0.060)\end{array}$ \\
\hline European & $\begin{array}{l}0.045 \\
(0.052)\end{array}$ & $\begin{array}{l}0.051 \\
(0.053)\end{array}$ & & $\begin{array}{l}0.095 \\
(0.061)\end{array}$ \\
\hline Observations & 1263 & 1263 & 336 & 927 \\
\hline R-squared & 0.11 & 0.09 & 0.09 & 0.11 \\
\hline
\end{tabular}

Robust standard errors in parentheses

* significant at $10 \%$; ** significant at $5 \%$; ${ }^{* \star \star}$ significant at $1 \%$ 
Table 5: Earnings equations for the total sample

\begin{tabular}{|c|c|c|c|c|c|c|c|c|c|}
\hline & \multicolumn{3}{|c|}{ OLS Estimation } & \multicolumn{3}{|c|}{ IV Estimation } & \multicolumn{3}{|c|}{ Two-Stage estimation } \\
\hline & Total & Females & Males & Total & Females & Males & Total & Females & Males \\
\hline Intermarriage dummy & $\begin{array}{l}0.062 \\
(0.020)^{\star \star \star}\end{array}$ & $\begin{array}{l}0.093 \\
(0.044)^{\star \star}\end{array}$ & $\begin{array}{l}0.052 \\
(0.023)^{\star \star}\end{array}$ & $\begin{array}{l}0.248 \\
(0.100)^{\star \star}\end{array}$ & $\begin{array}{l}0.766 \\
(0.376)^{\star \star}\end{array}$ & $\begin{array}{l}0.153 \\
(0.10)\end{array}$ & $\begin{array}{l}0.362 \\
(0.090)^{\star \star \star}\end{array}$ & $\begin{array}{l}0.937 \\
(0.249)^{\star \star \star}\end{array}$ & $\begin{array}{l}0.268 \\
(0.095)^{\star \star \star}\end{array}$ \\
\hline Male dummy & $\begin{array}{l}0.192 \\
(0.021)^{\star \star \star}\end{array}$ & & & $\begin{array}{l}0.187 \\
(0.022)^{\star \star \star}\end{array}$ & & & $\begin{array}{l}0.186 \\
(0.022)^{\star \star \star}\end{array}$ & & \\
\hline Age & $\begin{array}{l}0.019 \\
(0.007)^{\star \star \star}\end{array}$ & $\begin{array}{l}0.024 \\
(0.017)\end{array}$ & $\begin{array}{l}0.021 \\
(0.008)^{\star \star}\end{array}$ & $\begin{array}{l}0.017 \\
(0.007)^{\star \star}\end{array}$ & $\begin{array}{l}0.003 \\
(0.024)\end{array}$ & $\begin{array}{l}0.021 \\
(0.008)^{\star \star}\end{array}$ & $\begin{array}{l}0.015 \\
(0.007)^{\star \star}\end{array}$ & $\begin{array}{l}-0.004 \\
(0.019)\end{array}$ & $\begin{array}{l}0.02 \\
(0.008)^{\star \star}\end{array}$ \\
\hline $\mathrm{Age}^{2}$ & $\begin{array}{l}-0.024 \\
(0.009)^{\star \star \star}\end{array}$ & $\begin{array}{l}-0.027 \\
(0.023)\end{array}$ & $\begin{array}{l}-0.026 \\
(0.010)^{\star \star \star}\end{array}$ & $\begin{array}{l}-0.018 \\
(0.010)^{\star}\end{array}$ & $\begin{array}{l}0.006 \\
(0.034)\end{array}$ & $\begin{array}{l}-0.024 \\
(0.010)^{\star \star}\end{array}$ & $\begin{array}{l}-0.014 \\
(0.009)\end{array}$ & $\begin{array}{l}0.017 \\
(0.028)\end{array}$ & $\begin{array}{l}-0.022 \\
(0.010)^{\star \star}\end{array}$ \\
\hline Secondary education & $\begin{array}{l}0.009 \\
(0.022)\end{array}$ & $\begin{array}{l}0.058 \\
(0.060)\end{array}$ & $\begin{array}{l}0.003 \\
(0.023)\end{array}$ & $\begin{array}{l}-0.009 \\
(0.024)\end{array}$ & $\begin{array}{l}0.011 \\
(0.069)\end{array}$ & $\begin{array}{l}-0.007 \\
(0.025)\end{array}$ & $\begin{array}{l}-0.022 \\
(0.023)\end{array}$ & $\begin{array}{l}-0.014 \\
(0.070)\end{array}$ & $\begin{array}{l}-0.021 \\
(0.024)\end{array}$ \\
\hline Above Secondary education & $\begin{array}{l}0.402 \\
(0.048)^{\star \star \star}\end{array}$ & $\begin{array}{l}0.572 \\
(0.111)^{\star \star \star}\end{array}$ & $\begin{array}{l}0.368 \\
(0.053)^{\star \star \star}\end{array}$ & $\begin{array}{l}0.348 \\
(0.054)^{\star \star \star}\end{array}$ & $\begin{array}{l}0.448 \\
(0.154)^{\star \star \star}\end{array}$ & $\begin{array}{l}0.337 \\
(0.058)^{\star \star \star}\end{array}$ & $\begin{array}{l}0.316 \\
(0.052)^{\star \star \star}\end{array}$ & $\begin{array}{l}0.407 \\
(0.121)^{\star \star \star}\end{array}$ & $\begin{array}{l}0.303 \\
(0.057)^{\star \star \star}\end{array}$ \\
\hline Year since migration & $\begin{array}{l}0.007 \\
(0.002)^{\star \star \star}\end{array}$ & $\begin{array}{l}0.006 \\
(0.004)\end{array}$ & $\begin{array}{l}0.007 \\
(0.002)^{\star \star \star}\end{array}$ & $\begin{array}{l}0.005 \\
(0.002)^{\star \star}\end{array}$ & $\begin{array}{l}-0.005 \\
(0.009)\end{array}$ & $\begin{array}{l}0.006 \\
(0.002)^{\star \star \star}\end{array}$ & $\begin{array}{l}0.004 \\
(0.002)^{\star}\end{array}$ & $\begin{array}{l}-0.008 \\
(0.006)\end{array}$ & $\begin{array}{l}0.005 \\
(0.002)^{\star \star}\end{array}$ \\
\hline French fluent & $\begin{array}{l}0.02 \\
(0.018)\end{array}$ & $\begin{array}{l}0.039 \\
(0.044)\end{array}$ & $\begin{array}{l}0.008 \\
(0.019)\end{array}$ & $\begin{array}{l}-0.009 \\
(0.023)\end{array}$ & $\begin{array}{l}-0.052 \\
(0.066)\end{array}$ & $\begin{array}{l}-0.009 \\
(0.025)\end{array}$ & $\begin{array}{l}-0.029 \\
(0.021)\end{array}$ & $\begin{array}{l}-0.083 \\
(0.049)^{*}\end{array}$ & $\begin{array}{l}-0.031 \\
(0.023)\end{array}$ \\
\hline French before migration & $\begin{array}{l}0.086 \\
(0.020)^{\star \star \star}\end{array}$ & $\begin{array}{l}-0.007 \\
(0.066)\end{array}$ & $\begin{array}{l}0.104 \\
(0.021)^{\star \star \star}\end{array}$ & $\begin{array}{l}0.078 \\
(0.021)^{\star \star \star}\end{array}$ & $\begin{array}{l}-0.122 \\
(0.090)\end{array}$ & $\begin{array}{l}0.101 \\
(0.021)^{\star \star \star}\end{array}$ & $\begin{array}{l}0.075 \\
(0.021)^{\star \star \star}\end{array}$ & & $\begin{array}{l}0.1 \\
(0.021)^{\star \star \star}\end{array}$ \\
\hline No religious belief & $\begin{array}{l}0.032 \\
(0.022)\end{array}$ & $\begin{array}{l}0.056 \\
(0.052)\end{array}$ & $\begin{array}{l}0.027 \\
(0.024)\end{array}$ & $\begin{array}{l}0.02 \\
(0.023)\end{array}$ & $\begin{array}{l}-0.026 \\
(0.070)\end{array}$ & $\begin{array}{l}0.02 \\
(0.025)\end{array}$ & $\begin{array}{l}0.013 \\
(0.023)\end{array}$ & $\begin{array}{l}-0.039 \\
(0.058)\end{array}$ & $\begin{array}{l}0.015 \\
(0.025)\end{array}$ \\
\hline Parise & $\begin{array}{l}0.099 \\
(0.018)^{\star \star \star}\end{array}$ & $\begin{array}{l}0.024 \\
(0.042)\end{array}$ & $\begin{array}{l}0.122 \\
(0.020)^{\star \star \star}\end{array}$ & $\begin{array}{l}0.116 \\
(0.020)^{\star \star \star}\end{array}$ & $\begin{array}{l}0.096 \\
(0.062)\end{array}$ & $\begin{array}{l}0.132 \\
(0.021)^{\star \star \star}\end{array}$ & $\begin{array}{l}0.124 \\
(0.019)^{\star \star \star}\end{array}$ & $\begin{array}{l}0.104 \\
(0.052)^{\star \star}\end{array}$ & $\begin{array}{l}0.14 \\
(0.021)^{\star \star \star}\end{array}$ \\
\hline Africans & $\begin{array}{l}-0.039 \\
(0.030)\end{array}$ & $\begin{array}{l}0.034 \\
(0.080)\end{array}$ & $\begin{array}{l}-0.048 \\
(0.033)\end{array}$ & $\begin{array}{l}-0.066 \\
(0.033)^{\star \star}\end{array}$ & $\begin{array}{l}-0.107 \\
(0.122)\end{array}$ & $\begin{array}{l}-0.064 \\
(0.035)^{\star}\end{array}$ & $\begin{array}{l}-0.083 \\
(0.032)^{\star \star \star}\end{array}$ & $\begin{array}{l}-0.126 \\
(0.101)\end{array}$ & $\begin{array}{l}-0.081 \\
(0.034)^{\star \star}\end{array}$ \\
\hline Asians & $\begin{array}{l}0.115 \\
(0.037)^{\star \star \star}\end{array}$ & $\begin{array}{l}0.169 \\
(0.082)^{\star \star}\end{array}$ & $\begin{array}{l}0.091 \\
(0.044)^{\star *}\end{array}$ & $\begin{array}{l}0.09 \\
(0.040)^{\star \star}\end{array}$ & $\begin{array}{l}0.04 \\
(0.125)\end{array}$ & $\begin{array}{l}0.076 \\
(0.046)\end{array}$ & $\begin{array}{l}0.078 \\
(0.039)^{\star \star}\end{array}$ & $\begin{array}{l}0.047 \\
(0.101)\end{array}$ & $\begin{array}{l}0.061 \\
(0.045)\end{array}$ \\
\hline Europeans & $\begin{array}{l}0.032 \\
(0.027)\end{array}$ & $\begin{array}{l}0.012 \\
(0.069)\end{array}$ & $\begin{array}{l}0.047 \\
(0.029)\end{array}$ & $\begin{array}{l}-0.021 \\
(0.039)\end{array}$ & $\begin{array}{l}-0.176 \\
(0.131)\end{array}$ & $\begin{array}{l}0.018 \\
(0.042)\end{array}$ & $\begin{array}{l}-0.052 \\
(0.035)\end{array}$ & $\begin{array}{l}-0.222 \\
(0.098)^{\star \star}\end{array}$ & $\begin{array}{l}-0.016 \\
(0.038)\end{array}$ \\
\hline Constant & $\begin{array}{l}2.883 \\
(0.138)^{\star \star \star}\end{array}$ & $\begin{array}{l}2.821 \\
(0.310)^{\star \star *}\end{array}$ & $\begin{array}{l}3.051 \\
(0.163)^{\star \star \star}\end{array}$ & $\begin{array}{l}2.96 \\
(0.146)^{\star \star \star}\end{array}$ & $\begin{array}{l}3.488 \\
(0.518)^{\star \star \star}\end{array}$ & $\begin{array}{l}3.069 \\
(0.164)^{\star \star \star}\end{array}$ & $\begin{array}{l}3.007 \\
(0.142)^{\star \star \star}\end{array}$ & $\begin{array}{l}3.533 \\
(0.390)^{\star \star \star}\end{array}$ & $\begin{array}{l}3.084 \\
(0.164)^{\star \star \star}\end{array}$ \\
\hline Observations & 2222 & 557 & 1665 & 2222 & 557 & 1665 & 2222 & 523 & 1665 \\
\hline R-squared & 0.18 & 0.15 & 0.17 & & & & 0.18 & 0.16 & 0.17 \\
\hline
\end{tabular}

* significant at 10\%; ** significant at $5 \%$; ${ }^{* *}$ significant at $1 \%$ 
Table 6: Estimated results for females with sample selection correction

\begin{tabular}{|c|c|c|c|}
\hline & OLS & IV & Two-Stage \\
\hline Intermarriage dummy & $\begin{array}{l}0.097 \\
(0.043)^{\star \star}\end{array}$ & $\begin{array}{l}0.943 \\
(0.369)^{\star \star}\end{array}$ & $\begin{array}{l}0.954 \\
(0.225)^{\star \star \star}\end{array}$ \\
\hline Age & $\begin{array}{l}0.033 \\
(0.018)^{\star}\end{array}$ & $\begin{array}{l}0.014 \\
(0.03)\end{array}$ & $\begin{array}{l}0.014 \\
(0.02)\end{array}$ \\
\hline $\operatorname{Age}^{2}$ & $\begin{array}{l}-0.04 \\
(0.024)^{\star}\end{array}$ & $\begin{array}{l}-0.007 \\
(0.04)\end{array}$ & $\begin{array}{l}-0.01 \\
(0.03)\end{array}$ \\
\hline Secondary education & $\begin{array}{l}0.062 \\
(0.06)\end{array}$ & $\begin{array}{l}0.015 \\
(0.07)\end{array}$ & $\begin{array}{l}-0.006 \\
(0.07)\end{array}$ \\
\hline Above Secondary education & $\begin{array}{l}0.586 \\
(0.111)^{\star \star \star}\end{array}$ & $\begin{array}{l}0.444 \\
(0.161)^{\star \star \star}\end{array}$ & $\begin{array}{l}0.432 \\
(0.117)^{\star \star \star}\end{array}$ \\
\hline Year since migration & $\begin{array}{l}0.006 \\
(0.00)\end{array}$ & $\begin{array}{l}-0.008 \\
(0.01)\end{array}$ & $\begin{array}{l}-0.007 \\
(0.01)\end{array}$ \\
\hline French fluent & $\begin{array}{l}0.03 \\
(0.04)\end{array}$ & $\begin{array}{l}-0.088 \\
(0.07)\end{array}$ & $\begin{array}{l}-0.102 \\
(0.049)^{\star \star}\end{array}$ \\
\hline French before migration & $\begin{array}{l}0.016 \\
(0.07)\end{array}$ & $\begin{array}{l}-0.125 \\
(0.08)\end{array}$ & \\
\hline No religious belief & $\begin{array}{l}0.051 \\
(0.05)\end{array}$ & $\begin{array}{l}-0.054 \\
(0.07)\end{array}$ & $\begin{array}{l}-0.058 \\
(0.06)\end{array}$ \\
\hline Paris & $\begin{array}{l}0.051 \\
(0.04)\end{array}$ & $\begin{array}{l}0.145 \\
(0.072)^{\star \star}\end{array}$ & $\begin{array}{l}0.156 \\
(0.059)^{\star \star \star}\end{array}$ \\
\hline Africans & $\begin{array}{l}0.035 \\
(0.08)\end{array}$ & $\begin{array}{l}-0.142 \\
(0.12)\end{array}$ & $\begin{array}{l}-0.125 \\
(0.10)\end{array}$ \\
\hline Asians & $\begin{array}{l}0.192 \\
(0.079)^{\star \star}\end{array}$ & $\begin{array}{l}0.037 \\
(0.12)\end{array}$ & $\begin{array}{l}0.089 \\
(0.09)\end{array}$ \\
\hline Europeans & $\begin{array}{l}0.072 \\
(0.07)\end{array}$ & $\begin{array}{l}-0.134 \\
(0.13)\end{array}$ & $\begin{array}{l}-0.118 \\
(0.09)\end{array}$ \\
\hline Invers Mill's Ratio & $\begin{array}{l}0.166 \\
(0.11)\end{array}$ & $\begin{array}{l}0.269 \\
(0.138)^{\star}\end{array}$ & $\begin{array}{l}0.311 \\
(0.120)^{\star \star \star}\end{array}$ \\
\hline Constant & $\begin{array}{l}2.48 \\
(0.371)^{\star \star \star}\end{array}$ & $\begin{array}{l}3.106 \\
(0.523)^{\star \star \star}\end{array}$ & $\begin{array}{l}2.927 \\
(0.391)^{\star \star \star}\end{array}$ \\
\hline Observations & 557 & 557 & 523 \\
\hline R-squared & 0.15 & & 0.18 \\
\hline
\end{tabular}

Robust standard errors in parentheses

* significant at $10 \%$; ** significant at $5 \%$; *** significant at $1 \%$ 
Table7: Earnings equation for African and non-African samples separately

\begin{tabular}{|c|c|c|c|c|c|c|c|c|c|}
\hline & \multicolumn{3}{|c|}{ OLS } & \multicolumn{3}{|c|}{ IV Estimation } & \multicolumn{3}{|c|}{ "Two-Stage Estimation } \\
\hline & \multicolumn{2}{|c|}{ Africans } & \multirow[t]{2}{*}{ Non-Africans } & \multicolumn{2}{|c|}{ Africans } & \multirow[t]{2}{*}{ Non-Africans } & \multicolumn{2}{|c|}{ Africans } & \multirow[t]{2}{*}{ Non-Africans } \\
\hline & $\begin{array}{l}\text { Total African } \\
\text { sample }\end{array}$ & $\begin{array}{l}\text { French before } \\
\text { and fluently } \\
\text { now }\end{array}$ & & $\begin{array}{l}\text { Total African } \\
\text { sample }\end{array}$ & $\begin{array}{l}\text { French before } \\
\text { and fluently } \\
\text { now }\end{array}$ & & $\begin{array}{l}\text { Total } \\
\text { African } \\
\text { sample }\end{array}$ & $\begin{array}{l}\text { French } \\
\text { before and } \\
\text { fluently now }\end{array}$ & \\
\hline Intermarriage dummy & $\begin{array}{l}0.109 \\
(0.037)^{\star \star \star}\end{array}$ & $\begin{array}{l}0.112 \\
(0.045)^{\star \star}\end{array}$ & $\begin{array}{l}0.038 \\
(0.02)\end{array}$ & $\begin{array}{l}0.309 \\
(0.176)^{\star}\end{array}$ & $\begin{array}{l}0.493 \\
(0.239)^{\star \star}\end{array}$ & $\begin{array}{l}0.136 \\
(0.14)\end{array}$ & $\begin{array}{l}0.348 \\
(0.179)^{\star}\end{array}$ & $\begin{array}{l}0.481 \\
(0.230)^{\star \star}\end{array}$ & $\begin{array}{l}0.288 \\
(0.108)^{\star \star \star}\end{array}$ \\
\hline Male dummy & $\begin{array}{l}0.114 \\
(0.049)^{\star \star}\end{array}$ & $\begin{array}{l}0.053 \\
(0.062)\end{array}$ & $\begin{array}{l}0.216 \\
(0.024)^{\star \star \star}\end{array}$ & $\begin{array}{l}0.107 \\
(0.051)^{\star \star}\end{array}$ & $\begin{array}{l}0.058 \\
(0.064)\end{array}$ & $\begin{array}{l}0.216 \\
(0.025)^{\star \star \star}\end{array}$ & $\begin{array}{l}0.11 \\
(0.050)^{\star \star}\end{array}$ & $\begin{array}{l}0.068 \\
(0.062)\end{array}$ & $\begin{array}{l}0.208 \\
(0.025)^{\star \star \star}\end{array}$ \\
\hline Age & $\begin{array}{l}0.018 \\
(0.02)\end{array}$ & $\begin{array}{l}0.039 \\
(0.017)^{\star \star}\end{array}$ & $\begin{array}{l}0.019 \\
(0.008)^{\star \star}\end{array}$ & $\begin{array}{l}0.025 \\
(0.02)\end{array}$ & $\begin{array}{l}0.054 \\
(0.021)^{\star \star}\end{array}$ & $\begin{array}{l}0.015 \\
(0.01)\end{array}$ & $\begin{array}{l}0.027 \\
(0.02)\end{array}$ & $\begin{array}{l}0.058 \\
(0.022)^{\star \star \star}\end{array}$ & $\begin{array}{l}0.01 \\
(0.01)\end{array}$ \\
\hline $\mathrm{Age}^{2}$ & $\begin{array}{l}-0.023 \\
(0.02)\end{array}$ & $\begin{array}{l}-0.046 \\
(0.021)^{\star \star}\end{array}$ & $\begin{array}{l}-0.022 \\
(0.010)^{\star \star}\end{array}$ & $\begin{array}{l}-0.03 \\
(0.02)\end{array}$ & $\begin{array}{l}-0.058 \\
(0.024)^{\star \star}\end{array}$ & $\begin{array}{l}-0.017 \\
(0.01)\end{array}$ & $\begin{array}{l}-0.032 \\
(0.02)\end{array}$ & $\begin{array}{l}-0.063 \\
(0.025)^{\star \star}\end{array}$ & $\begin{array}{l}-0.008 \\
(0.01)\end{array}$ \\
\hline Secondary education & $\begin{array}{l}-0.006 \\
(0.04)\end{array}$ & $\begin{array}{l}-0.009 \\
(0.065)\end{array}$ & $\begin{array}{l}0.013 \\
(0.03)\end{array}$ & $\begin{array}{l}-0.02 \\
(0.04)\end{array}$ & $\begin{array}{l}-0.031 \\
(0.067)\end{array}$ & $\begin{array}{l}0.004 \\
(0.03)\end{array}$ & $\begin{array}{l}-0.033 \\
(0.05)\end{array}$ & $\begin{array}{l}-0.059 \\
(0.076)\end{array}$ & $\begin{array}{l}-0.009 \\
(0.03)\end{array}$ \\
\hline Above Secondary education & $\begin{array}{l}0.353 \\
(0.073)^{\star \star \star}\end{array}$ & $\begin{array}{l}0.398 \\
(0.093)^{\star \star \star}\end{array}$ & $\begin{array}{l}0.433 \\
(0.063)^{\star \star \star}\end{array}$ & $\begin{array}{l}0.29 \\
(0.085)^{\star \star \star}\end{array}$ & $\begin{array}{l}0.276 \\
(0.116)^{\star \star}\end{array}$ & $\begin{array}{l}0.423 \\
(0.065)^{\star \star \star}\end{array}$ & $\begin{array}{l}0.272 \\
(0.091)^{\star \star \star}\end{array}$ & $\begin{array}{l}0.26 \\
(0.127)^{\star \star}\end{array}$ & $\begin{array}{l}0.41 \\
(0.063)^{\star \star \star}\end{array}$ \\
\hline Year since migration & $\begin{array}{l}0.007 \\
(0.002)^{\star \star \star \star}\end{array}$ & $\begin{array}{l}0.009 \\
(0.004)^{\star \star}\end{array}$ & $\begin{array}{l}0.009 \\
(0.002)^{\star \star \star}\end{array}$ & $\begin{array}{l}0.006 \\
(0.003)^{\star \star}\end{array}$ & $\begin{array}{l}0.006 \\
(0.004)\end{array}$ & $\begin{array}{l}0.007 \\
(0.004)^{\star}\end{array}$ & $\begin{array}{l}0.006 \\
(0.003)^{\star \star}\end{array}$ & $\begin{array}{l}0.006 \\
(0.004)\end{array}$ & $\begin{array}{l}0.004 \\
-0.003\end{array}$ \\
\hline French fluent & $\begin{array}{l}-0.022 \\
(0.03)\end{array}$ & & $\begin{array}{l}0.036 \\
(0.022)^{*}\end{array}$ & $\begin{array}{l}-0.051 \\
(0.04)\end{array}$ & & $\begin{array}{l}0.018 \\
(0.03)\end{array}$ & $\begin{array}{l}-0.06 \\
(0.04)\end{array}$ & & $\begin{array}{l}-0.005 \\
(0.03)\end{array}$ \\
\hline French before migration & $\begin{array}{l}0.048 \\
(0.04)\end{array}$ & & $\begin{array}{l}0.094 \\
(0.026)^{\star \star \star}\end{array}$ & $\begin{array}{l}0.032 \\
(0.04)\end{array}$ & & $\begin{array}{l}0.089 \\
(0.027)^{\star \star \star}\end{array}$ & $\begin{array}{l}0.033 \\
(0.04)\end{array}$ & & $\begin{array}{l}0.085 \\
(0.027)^{\star \star \star}\end{array}$ \\
\hline No religious belief & $\begin{array}{l}0.097 \\
(0.037)^{\star \star \star}\end{array}$ & $\begin{array}{l}-0.024 \\
(0.042)\end{array}$ & $\begin{array}{l}0.016 \\
-0.029\end{array}$ & $\begin{array}{l}0.094 \\
(0.037)^{\star \star}\end{array}$ & $\begin{array}{l}-0.081 \\
(0.055)\end{array}$ & $\begin{array}{l}0.006 \\
-0.031\end{array}$ & $\begin{array}{l}0.101 \\
(0.037)^{\star \star \star}\end{array}$ & $\begin{array}{l}-0.09 \\
(0.055)^{\star}\end{array}$ & $\begin{array}{l}-0.007 \\
-0.03\end{array}$ \\
\hline Paris & $\begin{array}{l}0.063 \\
(0.030)^{\star \star}\end{array}$ & $\begin{array}{l}0.028 \\
(0.040)\end{array}$ & $\begin{array}{l}0.114 \\
(0.024)^{\star \star \star}\end{array}$ & $\begin{array}{l}0.073 \\
(0.030)^{\star \star}\end{array}$ & $\begin{array}{l}0.072 \\
(0.045)\end{array}$ & $\begin{array}{l}0.126 \\
(0.029)^{\star \star \star}\end{array}$ & $\begin{array}{l}0.069 \\
(0.030)^{\star \star}\end{array}$ & $\begin{array}{l}0.057 \\
(0.041)\end{array}$ & $\begin{array}{l}0.144 \\
(0.027)^{\star \star \star}\end{array}$ \\
\hline Asians & & & $\begin{array}{l}0.114 \\
(0.039)^{\star \star \star}\end{array}$ & & & $\begin{array}{l}0.102 \\
(0.045)^{\star \star}\end{array}$ & & & $\begin{array}{l}0.074 \\
(0.042)^{\star}\end{array}$ \\
\hline Europeans & & & $\begin{array}{l}0.028 \\
(0.03)\end{array}$ & & & $\begin{array}{l}0.009 \\
(0.04)\end{array}$ & & & $\begin{array}{l}-0.021 \\
(0.03)\end{array}$ \\
\hline Constant & $\begin{array}{l}2.989 \\
(0.351)^{\star \star \star}\end{array}$ & $\begin{array}{l}2.716 \\
(0.339)^{\star \star \star}\end{array}$ & $\begin{array}{l}2.849 \\
(0.152)^{\star \star \star}\end{array}$ & $\begin{array}{l}2.811 \\
(0.404)^{\star \star \star}\end{array}$ & $\begin{array}{l}2.285 \\
(0.453)^{\star \star \star}\end{array}$ & $\begin{array}{l}2.929 \\
(0.200)^{\star \star \star}\end{array}$ & $\begin{array}{l}2.764 \\
(0.428)^{\star \star \star}\end{array}$ & $\begin{array}{l}2.241 \\
(0.458)^{\star \star \star}\end{array}$ & $\begin{array}{l}3.068 \\
(0.179)^{\star \star \star}\end{array}$ \\
\hline Observations & 760 & 482 & 1462 & 760 & 482 & 1462 & 760 & 482 & 1462 \\
\hline R-squared & 0.15 & 0.15 & 0.2 & & & & 0.15 & 0.15 & 0.2 \\
\hline
\end{tabular}

* significant at 10\%; ** significant at 5\%; *** significant at 1\% 
Table 8: Earnings equation for whether speaking French before migration

\begin{tabular}{|c|c|c|c|c|c|c|}
\hline & \multicolumn{3}{|c|}{ Speaking French Before Immigration } & \multicolumn{3}{|c|}{ Did not speak French Before Immigration } \\
\hline & OLS & IV Estimation & Two-Stage Estimation & OLS & IV Estimation & Two-Stage Estimation \\
\hline \multirow[t]{2}{*}{ Intermarriage dummy } & 0.055 & 0.419 & 0.513 & 0.067 & -0.133 & 0.125 \\
\hline & $(0.027)^{\star \star}$ & $(0.149)^{\star \star \star}$ & $(0.142)^{\star \star \star}$ & $(0.032)^{\star \star}$ & -0.194 & $(0.158)$ \\
\hline \multirow[t]{2}{*}{ Male dummy } & 0.167 & 0.157 & 0.155 & 0.236 & 0.234 & 0.236 \\
\hline & $(0.027)^{\star \star \star}$ & $(0.030)^{\star \star \star}$ & $(0.028)^{\star \star \star}$ & $(0.035)^{\star \star \star}$ & $(0.036)^{\star \star \star}$ & $(0.035)^{\star \star \star}$ \\
\hline \multirow[t]{2}{*}{ Age } & 0.025 & 0.022 & 0.02 & 0.003 & 0.006 & 0.002 \\
\hline & $(0.010)^{\star \star}$ & $(0.011)^{\star \star}$ & $(0.010)^{\star *}$ & $(0.010)$ & $(0.011)$ & $(0.010)$ \\
\hline $\mathrm{Age}^{2}$ & -0.032 & -0.023 & -0.019 & -0.003 & -0.008 & -0.001 \\
\hline \multirow[t]{2}{*}{ Secondary education } & -0.003 & -0.048 & -0.058 & 0.009 & 0.028 & 0.003 \\
\hline & $(0.047)$ & $(0.050)$ & $(0.049)$ & $(0.025)$ & $(0.031)$ & $(0.028)$ \\
\hline \multirow{2}{*}{ Above Secondary educ } & c 0.404 & 0.284 & 0.259 & 0.058 & 0.082 & 0.053 \\
\hline & $(0.063)^{\star \star \star}$ & $(0.078)^{\star \star \star}$ & $(0.073)^{\star \star \star}$ & $(0.160)$ & $(0.166)$ & $(0.158)$ \\
\hline \multirow[t]{2}{*}{ Year since migration } & 0.009 & 0.004 & 0.003 & 0.006 & 0.007 & 0.006 \\
\hline & $(0.002)^{\star \star \star}$ & $(0.003)$ & $(0.003)$ & $(0.003)^{\star}$ & $(0.004)^{\star \star}$ & $(0.003)$ \\
\hline \multirow[t]{2}{*}{ French fluent } & -0.003 & -0.057 & -0.071 & 0.059 & 0.089 & 0.05 \\
\hline & $(0.024)$ & $(0.031)^{\star}$ & $(0.029)^{\star \star}$ & $(0.026)^{\star \star}$ & $(0.039)^{\star \star}$ & $(0.033)$ \\
\hline No religious belief & 0.132 & 0.125 & 0.128 & 0.067 & 0.092 & 0.06 \\
\hline \multirow[t]{2}{*}{ Paris } & 0.092 & 0.119 & 0.124 & 0.106 & 0.085 & 0.111 \\
\hline & $(0.025)^{\star \star \star}$ & $(0.028)^{\star \star \star}$ & $(0.026)^{\star \star \star}$ & $(0.027)^{\star \star \star}$ & $(0.033)^{\star \star \star}$ & $(0.030)^{\star \star \star}$ \\
\hline \multirow[t]{2}{*}{ Africans } & 0.023 & -0.082 & -0.109 & -0.095 & -0.08 & -0.1 \\
\hline & $(0.050)$ & $(0.066)$ & $(0.064)^{\star}$ & $(0.036)^{\star \star \star}$ & $(0.039)^{\star \star}$ & $(0.038)^{\star \star \star}$ \\
\hline \multirow[t]{2}{*}{ Asians } & 0.176 & 0.092 & 0.071 & 0.061 & 0.079 & 0.055 \\
\hline & $(0.063)^{\star \star *}$ & $(0.077)$ & $(0.071)$ & $(0.046)$ & $(0.051)$ & $(0.049)$ \\
\hline \multirow[t]{2}{*}{ Europeans } & 0.071 & -0.111 & -0.158 & 0.027 & 0.042 & 0.022 \\
\hline & $(0.047)$ & (0.089) & $(0.085)^{*}$ & $(0.034)$ & $(0.038)$ & $(0.037)$ \\
\hline \multirow[t]{2}{*}{ Constant } & 2.746 & 2.9 & 2.941 & 3.215 & 3.128 & 3.239 \\
\hline & $(0.177)^{\star \star \star}$ & $(0.197)^{\star \star \star}$ & $(0.185)^{\star \star \star}$ & $(0.207)^{\star \star \star}$ & $(0.231)^{\star \star *}$ & $(0.216)^{\star \star \star}$ \\
\hline Number of obs. & 1380 & 1380 & 1380 & 842 & 842 & 842 \\
\hline R-squared & 0.19 & & 0.19 & 0.14 & & 0.14 \\
\hline
\end{tabular}

Robust standard errors in parentheses

* significant at $10 \%$; ** significant at $5 \%$; *** significant at $1 \%$ 